\author{
Marzena Mularzuk, Henryk Skarżyński, \\ Agata Szkiełkowska, Natalia Czajka \\ Instytut Fizjologii i Patologii Słuchu w Warszawie
}

\title{
Ewaluacja testu uwagi słuchowej u dzieci ze specjalnymi potrzebami edukacyjnymi po zastosowaniu terapii dźwiękowej
}

Zaburzenia uwagi słuchowej manifestujące się deficytami w zakresie opracowywania i percepcji informacji akustycznej są zjawiskiem dość powszechnie występującymi wśród dzieci i młodzieży. Zaburzeniom uwagi słuchowej często towarzyszą trudności w zakresie nabywania umiejętności czytania i pisania, rozumienia poleceń, nadpobudliwość psychoruchowa i zaburzenia koncentracji. Dzieci dotknięte zaburzeniami uwagi słuchowej osiągają gorsze rezultaty w nauce. Poprawa umiejętności segregacji percepcyjnej dzięki zastosowaniu treningu słuchowego w postaci terapii dźwiękowej pozwala na wyrównywanie szans edukacyjnych uczniów ze specjalnymi potrzebami edukacyjnymi.

Słowa kluczowe: uwaga słuchowa, test uwagi słuchowej, metoda Tomatisa

\section{Evaluation of the auditory attention test in children with special educational needs following the application of sound therapy}

Auditory attention disorders manifested in difficulties in development and perception of the auditory information are among the most common disorders presenting for treatment in children and adolescents. Auditory attention disorders are often associated with co-occurring disorders including difficulties in writing and reading and listening skills, understanding of commands, psychomotor hyperactivity and attention disorders, eventually resulting in poor school performance. Hence, improving auditory stream/processing segregation appears a disorder to being targeted for remediation and treatment with the usage of sound therapy in order to meet one's particular needs and equalize educational opportunities.

Keywords: auditory attention, test of auditory attention, the Tomatis method 


\section{Wprowadzenie}

Przedstawiciele różnych dziedzin nauki zajmujący się problematyką rozwoju mowy i języka u dzieci są zgodni, że wśród elementów mających kluczowe znaczenie dla prawidłowego kształtowania się komunikacji językowej są sprawnie funkcjonujący narząd słuchu oraz właściwie przebiegające procesy percepcji słuchowej [Kurkowski, Szkiełkowska i in. 2002]. W prawidłowym rozwoju tej niezwykle ważnej dla człowieka umiejętności rola słuchu jest nie do przecenienia, stanowi on bowiem najistotniejszą drogę odbioru informacji dźwiękowej [Pruszewicz 2003]. Udowodniono, że jeśli u małego dziecka nie zostaną uaktywnione funkcje słuchowe, nie osiągnie ono biegłego posługiwania się językiem [Gopnik, Cargo 1991]. Prawidłowa percepcja dźwięków warunkowana jest nie tylko przez sprawnie działający obwodowy narząd słuchu. Ważną rolę odgrywają także procesy zachodzące na wyższych piętrach drogi słuchowej. Istnieją zaburzenia, w których przy prawidłowym odbiorze bodźców w strukturach obwodowych występują trudności w zakresie pełnego wykorzystania słyszanego sygnału akustycznego. Są określone jako zaburzenia ośrodkowego przetwarzania słuchowego. Ważną składową procesów przetwarzania słuchowego jest uwaga słuchowa. Stanowi ona swoisty filtr w zakresie odbioru informacji dźwiękowych, pozwalając na selekcję informacji -zapercypowanie istotnych i odrzucenie nieistotnych.

Osoby dotknięte zaburzeniami uwagi słuchowej mogą być postrzegane jako niesłyszące lub niedosłyszące pomimo prawidłowego progu słyszenia. Często nie reagują one właściwie na komunikaty słowne, m.in. z powodu trudności $\mathrm{w}$ wyłowieniu konkretnej informacji z tła akustycznego. Zaburzenia $\mathrm{w}$ zakresie uwagi słuchowej u dzieci skutkują nie tylko problemami w sferze komunikacji językowej i nauki, lecz mogą negatywnie wpływać także na zachowanie. W sytuacji, kiedy dziecko nie radzi sobie z analizą i syntezą bodźców akustycznych, świat dźwięków odbierany jest przez nie jako źródło zagrożenia. Powoduje to mobilizację mechanizmów obronnych, a u dziecka wzrasta poziom napięcia i stresu, co może skutkować m.in. nasileniem zachowań agresywnych To dodatkowo potęguje problemy szkolne dziecka z zaburzeniami uwagi słuchowej. Zaburzenia ośrodkowego przetwarzania bodźców słuchowych nie są zjawiskiem rzadkim. Z licznych badań prowadzonych na świecie wynika, że zaburzenia te, skutkujące deficytami językowymi, ma duża grupa dzieci i dorosłych [Gopnik, Cargo 1991, Szuman 1963, Weiner 1974]. Natomiast z powszechnych badań przesiewowych słuchu przeprowadzonych w całej Polsce przez Instytut Fizjologii i Patologii Słuchu wśród uczniów z klas początkowych szkoły podstawowej wynika, że nieprawidłowy wynik testów w zakresie przetwarzania słuchowego miało prawie 15\% dzieci [Skarżyński, Czyżewski i in. 2007]. 
Dynamiczny rozwój medycyny (w zakresie diagnostyki, leczenia i rehabilitacji) oraz dyscyplin z nią współpracujących, w tym logopedii, psychologii, pedagogiki i inżynierii dźwięku, spowodował wzrost wiedzy i możliwości diagnostycznych u dzieci mających trudności w zakresie prawidłowego przyswajania mowy i języka na podłożu zaburzeń uwagi słuchowej.

W świetle obecnej wiedzy o plastyczności układu słuchowego i sensytywnych okresach rozwoju percepcji słuchowej u dzieci zasadne jest stosowanie treningów słuchowych, które w sposób dynamiczny kształtują uwagę słuchową.

\section{Metodologia badań własnych}

Celem podjętych badań własnych było uzyskanie informacji na temat dynamiki przebiegu parametrów testu uwagi i lateralizacji słuchowej u dzieci 7-letnich z zaburzeniami uwagi słuchowej, po zastosowaniu stymulacji dźwiękowej metodą Tomatisa. Materiał do pracy stanowiły badania wykonane wśród uczniów klas pierwszych u 422 dzieci z 78 szkół podstawowych powszechnych, integracyjnych i z oddziałami integracyjnymi z terenu całej Polski, w wieku 7 lat rozpoczynających naukę w klasie pierwszej, które uzyskały nieprawidłowy wynik w teście uwagi słuchowej oraz miały zbadane wszystkie parametry wchodzące w skład testu uwagi i lateralizacji słuchowej. Zgromadzony materiał badawczy podzielono na następujące grupy: dzieci zespołami zaburzeń genetycznych, dzieci z autyzmem, dzieci z zaburzeniami zachowania, dzieci z zaburzeniami mowy, dzieci z zaburzeniami rozwoju psychoruchowego, dzieci z prawidłowym rozwojem psychofizycznym. Kwalifikacja do poszczególnych grup badanych odbyła się na podstawie dokumentacji uczniów lub/i na podstawie orzeczenia lekarskiego.

Zgodnie z procedurą diagnostyczną stosowaną $\mathrm{w}$ metodzie Tomatisa wyznaczane zostały progi uwagi słuchowej obejmujące ocenę: uwagi słuchowej zewnętrznej dla tonów czystych od $125 \mathrm{~Hz}$ do $8000 \mathrm{~Hz}$., podawanych drogą powietrzną, uwagi słuchowej wewnętrznej dla tonów czystych o częstotliwości od $250 \mathrm{~Hz}$ do $4000 \mathrm{~Hz}$, podawanych drogą kostną z jednoczesną oceną umiejętności lokalizacji dźwięków, oraz test dyskryminacji wysokości dźwięków podawanych drogą powietrzną w odstępie jednej oktawy w paśmie częstotliwości 125-500 Hz i co pół oktawy w paśmie 750-8000 Hz.

Dla prawidłowego funkcjonowania słuchowego dziecka ważne jest oddzielenie uwagi zewnętrznej, związanej z percepcją wypowiedzi cudzych, i uwagi skierowanej na percepcję wypowiedzi własnych (autokontrolę słuchową), określanej jako uwaga słuchowa wewnętrzna, dokonywanie prawidłowej dyskryminacji wysokości dźwięku (funkcja rozróżniania wysokości dźwięków) oraz umiejęt- 
ność prawidłowej lokalizacji dźwięku, wpływająca na koordynację słuchowo-ruchową i słuchowo-wzrokową. W wykonanych analizach statystycznych porównywano wpływ interwencji $\mathrm{w}$ postaci terapii Tomatisa na zmianę częstości występowania poszczególnych poziomów uwagi słuchowej w testach wykonanych przed terapią i po terapii. Poziom uwagi słuchowej zewnętrznej oraz wyniki testu uwagi słuchowej - dyskryminacji wysokości dźwięku analizowane były $\mathrm{w}$ trzech przedziałach określanych $\mathrm{w}$ niniejszej pracy jako strefy częstotliwości: strefa I - obejmuje pasmo częstotliwości $125-750 \mathrm{~Hz}$, strefa II - obejmuje pasmo częstotliwości 1000-3000 Hz, strefa III - obejmuje pasmo częstotliwości od $4000 \mathrm{~Hz}$. Natomiast poziom uwagi słuchowej wewnętrznej oraz wyniki testu uwagi słuchowej - lokalizacji dźwięku analizowane były w trzech przedziałach określanych w niniejszej pracy jako strefy częstotliwości: strefa I - obejmuje pasmo częstotliwości $250-750 \mathrm{~Hz}$, strefa II - obejmuje pasmo częstotliwości $1000-3000 \mathrm{~Hz}$, strefa III - obejmuje pasmo częstotliwości od $4000 \mathrm{~Hz}$.

Zgodnie z nomenklaturą stosowną $\mathrm{w}$ metodzie Tomatisa, przyjęto określenie "progi słuchania" jako wskaźnik poziomu uwagi słuchowej w odróżnieniu od "progów słyszenia", które są wskaźnikiem poziomu recepcji dźwięków. Uwaga słuchowa (progi słuchania) w poszczególnych przedziałach częstotliwości była oceniana jako: prawidłowa uwaga słuchowa, obniżona uwaga słuchowa, podwyższona uwaga słuchowa. Nieprawidłowy wynik w teście uwagi słuchowej w zakresie uwagi słuchowej zewnętrznej i wewnętrznej stwierdzano wtedy, gdy w przynajmniej jednym paśmie częstotliwości wynik testu wskazywał na „obniżoną" lub „podwyższoną" uwagę słuchową. Za poprawę w teście uwagi słuchowej zewnętrznej i wewnętrznej uznawano takie badanie, w którym przed terapią uzyskano wynik „obniżona” lub „podwyższona” uwaga słuchowa w jednym z badanych przedziałów częstotliwości, a po przeprowadzonej terapii metodą Tomatisa poziom uwagi słuchowej określany była jako „prawidłowa” uwaga słuchowa w przynajmniej jednym z badanych przedziałów częstotliwości. Wynik uwaga słuchowa "bez zmian" oznaczał takie same wyniki uzyskane w testach uwagi słuchowej wykonanych przed terapią i po terapii Tomatisa, natomiast wynik „pogorszenie” uwagi słuchowej oznaczał zmianę wyniku „prawidłowa” uwaga słuchowa na „obniżona” lub „podwyższona” uwaga słuchowa po terapii. Poziom uwagi słuchowej analizowany $\mathrm{w}$ niniejszej pracy uznano, zgodnie $\mathrm{z}$ procedurą obowiązującą w metodzie Tomatisa, za "podwyższoną" lub „obniżoną" uwagę słuchową, jeśli odchylenie poziomu uwagi słuchowej wynosiło więcej niż $10 \mathrm{~dB}$ $\mathrm{w}$ stosunku do normy dla przynajmniej dwóch częstotliwości w danym paśmie częstotliwości [Szkiełkowska 2012]. Nieprawidłowy wynik w teście uwagi słuchowej w zakresie dyskryminacji wysokości dźwięku stwierdzano wtedy, gdy badane dziecko wykazało brak tej umiejętności w całym przedziale częstotliwości lub jego części. Nieprawidłowy wynik w teście uwagi słuchowej w zakresie lokalizacji 
dźwięku stwierdzano wtedy, gdy badane dziecko wykazało brak tej umiejętności w poszczególnych przedziałach częstotliwości.

Dzieci z grup badanych poddane zostały stymulacji dźwiękowej metodą Tomatisa. Terapia Tomatisa jest rodzajem treningu słuchowego polegającego na słuchaniu odpowiednio przygotowanego materiału dźwiękowego (na bazie chorałów gregoriańskich i muzyki Mozarta), gdzie sygnał muzyczny jest podawany przez specjalne słuchawki zarówno drogą powietrzną, jak i kostną. Zgodnie z przyjętą dla tej pracy procedurą terapeutyczną słuchanie obejmowało 3 serie stymulacji słuchowej. W czasie jednej serii dzieci poddawane były stymulacji dźwiękowej przez 2 godziny dziennie, przez $10 \mathrm{dni}$. Pomiędzy kolejnymi seriami były 4 tygodnie przerwy. W pierwszej fazie treningu - pasywnej, zastosowano klasyczne przetwarzanie materiału dźwiękowego z wykorzystaniem aparatury w postaci ucha elektronicznego, w której pacjent słucha biernie. $W$ drugiej fazie treningu - aktywnej, zastosowano przekształcone algorytmy dźwiękowe prezentowane za pomocą ucha elektronicznego i modyfikowane poprzez poddawanie mechanizmowi bramkowania i filtracji. Ciężar słuchania stopniowo przekierowywany był na prawe ucho, kształtując lateralizację słuchową. W aktywnej fazie terapii uczestnik stymulowany był również dźwiękami mowy i włączany do ich odtwarzania.

Przed rozpoczęciem terapii i po jej zakończeniu terapii wykonano u wszystkich dzieci test uwagi słuchowej w celu oceny efektów wdrożonych działań terapeutycznych. Podczas terapii nie stosowano wśród badanych dzieci innych metod terapeutycznych.

\section{Wyniki}

Przeprowadzone analizy potwierdzily przydatność stosowania testów uwagi słuchowej w diagnostyce dzieci z zaburzeniami przetwarzania słuchowego, koncentracji, rozwoju mowy i języka. Stosowane dotychczas w ramach programów edukacyjnych opisowe arkusze obserwacyjne uczniów mogą zatem zostać wzbogacone o nowe możliwości w zakresie diagnozy i stanowić pomoc dla pedagogów poszukujących metod wspomagania uczniów z zaburzeniami percepcji słuchowej. Zwiększyłoby to tym samym szanse tych dzieci na łatwiejszy i efektywniejszy rozwój edukacyjny.

W tabeli 1. przedstawiono liczbę i odsetek dzieci, u których w teście uwagi słuchowej zewnętrznej w uchu prawym oraz $w$ uchu lewym uzyskano wynik nieprawidłowy oraz liczbę i odsetek dzieci, u których uzyskano wynik „poprawa” po terapii Tomatisa, z podziałem na grupy badane. 
Tabela 1. Odsetek dzieci, u których w teście uwagi słuchowej zewnętrznej w uchu prawym i lewym uzyskano wynik nieprawidłowy, oraz odsetek dzieci, u których uzyskano wynik „poprawa” po terapii Tomatisa, z podziałem na poszczególne grupy badane, oraz wyniki uzyskane w grupie kontrolnej w badaniu 1 i 2

\begin{tabular}{|l|c|c|c|c|c|c|}
\hline \multirow{2}{*}{\multicolumn{1}{|c}{ Grupa badana }} & \multicolumn{4}{|c|}{ Ucho prawe } & \multicolumn{2}{c|}{ Ucho lewe } \\
\cline { 2 - 7 } & $\begin{array}{c}\text { wyniki nieprawidłowe } \\
\text { przed terapią }\end{array}$ & \multicolumn{2}{c|}{$\begin{array}{c}\text { efekt poprawy } \\
\text { po terapii }\end{array}$} & \multicolumn{2}{c|}{$\begin{array}{c}\text { wyniki nieprawidłowe } \\
\text { przed terapią }\end{array}$} \\
\cline { 2 - 7 } & $\mathrm{N}$ & $\%$ & $\mathrm{~N}$ & $\%$ & $\mathrm{~N}$ & $\%$ \\
\hline $\begin{array}{l}\text { zaburzenia z zespołami } \\
\text { genetycznymi }\end{array}$ & 63 & 84,0 & 36 & 57,1 & 53 & 70,7 \\
\hline autyzm & 45 & 69,2 & 27 & 60,0 & 52 & 80,0 \\
\hline zaburzenia zachowania & 42 & 72,4 & 28 & 66,7 & 34 & 58,6 \\
\hline zaburzenia mowy & 52 & 71,2 & 38 & 73,1 & 47 & 64,4 \\
\hline $\begin{array}{l}\text { zaburzenia rozwoju } \\
\text { psychoruchowego }\end{array}$ & 59 & 81,9 & 33 & 55,9 & 59 & 81,9 \\
\hline $\begin{array}{l}\text { prawidłowy rozwój } \\
\text { psychofizyczny }\end{array}$ & 62 & 78,5 & 54 & 87,1 & 56 & 70,9 \\
\hline $\begin{array}{l}\text { grupa kontrolna } \\
\text { (bez terapii) }\end{array}$ & 13 & 25,0 & 11 & 84,6 & 14 & 26,9 \\
\hline
\end{tabular}

Źródło: Badania własne.

Po przeanalizowaniu wyników testu uwagi słuchowej zewnętrznej w uchu prawym zaobserwowano znaczny efekt poprawy tychże wyników, wyrażony odsetkiem dzieci w każdej z grup badanych, u których w teście wykonanym po zakończeniu terapii metodą Tomatisa odnotowano poprawę wyników uwagi słuchowej $\mathrm{w}$ porównaniu $\mathrm{z}$ wynikami testu przeprowadzonego przed terapią. Wzrost ten wynosił 55,9\% w grupie dzieci z zaburzeniami rozwoju psychoruchowego i $87,1 \%$ w grupie dzieci z prawidłowym rozwojem psychoruchowym.

Częstość występowania wyników „nieprawidłowa” uwaga słuchowa zewnętrzna w uchu lewym była podobna jak w uchu prawym. O ile w uchu prawym wyniki testu wykonanego $\mathrm{w}$ grupie kontrolnej podczas badania pierwszego były podobne do wyników uzyskanych w większości badanych grup przed terapią Tomatisa, to w testach uwagi słuchowej przeprowadzonych po terapii występował znaczny wzrost wyniku "poprawa” uwagi słuchowej w każdej z badanych grup $\mathrm{w}$ porównaniu $\mathrm{z}$ testami przeprowadzonymi $\mathrm{w}$ grupie kontrolnej podczas badania drugiego. Po terapii Tomatisa najmniejszy wzrost liczby wyników oznaczających "poprawę" w testach uwagi słuchowej odnotowano w grupie dzieci z zaburzeniami zachowania, natomiast największy wzrost liczby wyników „poprawa" w teście uwagi słuchowej odnotowano w grupie dzieci z prawidłowym rozwojem psychofizycznym. 
$\mathrm{W}$ tabeli 2. przedstawiono liczbę i odsetek dzieci, u których w teście uwagi słuchowej wewnętrznej $\mathrm{w}$ uchu prawym oraz $\mathrm{w}$ uchu lewym uzyskano wynik nieprawidłowy oraz liczbę i odsetek dzieci, u których uzyskano wynik „poprawa” po terapii Tomatisa, z podziałem na grupy badane.

Tabela 2. Odsetek dzieci z grup badanych, u których w teście uwagi słuchowej wewnętrznej w uchu prawym i uchu lewym uzyskano przed terapią wynik „nieprawidłowa” uwaga słuchowa oraz liczba i odsetek dzieci, u których po terapii Tomatisa uzyskano wynik „poprawa” uwagi słuchowej, oraz wyniki uzyskane w grupie kontrolnej w badaniu 1 i 2

\begin{tabular}{|c|c|c|c|c|c|c|}
\hline \multirow{3}{*}{ Grupa badana } & \multicolumn{4}{|c|}{ Ucho prawe } & \multirow{2}{*}{\multicolumn{2}{|c|}{$\begin{array}{c}\text { Ucho lewe } \\
\text { wyniki nieprawidłowe } \\
\text { przed terapią }\end{array}$}} \\
\hline & \multicolumn{2}{|c|}{$\begin{array}{c}\text { wyniki nieprawidłowe } \\
\text { przed terapią }\end{array}$} & \multicolumn{2}{|c|}{$\begin{array}{c}\text { efekt poprawy } \\
\text { po terapii }\end{array}$} & & \\
\hline & $\mathrm{N}$ & $\%$ & $\mathrm{~N}$ & $\%$ & $\mathrm{~N}$ & $\%$ \\
\hline $\begin{array}{l}\text { zaburzenia z zespołami } \\
\text { genetycznymi }\end{array}$ & 39 & 52,0 & 36 & 92,3 & 42 & 56,0 \\
\hline autyzm & 40 & 61,5 & 33 & 82,5 & 32 & 49,2 \\
\hline zaburzenia zachowania & 32 & 55,2 & 18 & 56,3 & 38 & 65,5 \\
\hline zaburzenia mowy & 42 & 57,5 & 29 & 69,0 & 35 & 47,9 \\
\hline $\begin{array}{l}\text { zaburzenia rozwoju } \\
\text { psychoruchowego }\end{array}$ & 38 & 52,8 & 26 & 68,4 & 39 & 54,2 \\
\hline $\begin{array}{l}\text { prawidłowy rozwój } \\
\text { psychofizyczny }\end{array}$ & 36 & 45,6 & 29 & 80,6 & 41 & 51,9 \\
\hline $\begin{array}{l}\text { grupa kontrolna } \\
\text { (bez terapii) }\end{array}$ & 14 & 26,9 & 9 & 64,3 & 9 & 17,3 \\
\hline
\end{tabular}

Źródło: Badania własne.

Podobnie jak $\mathrm{w}$ badaniach przeprowadzonych przed terapią Tomatisa, dotyczących uwagi słuchowej zewnętrznej, również wyniki testów uwagi słuchowej wewnętrznej w uchu prawym charakteryzowały się występowaniem wysokiego odsetka wyników „nieprawidłowa” uwaga słuchowa. W grupie kontrolnej w badaniu pierwszym $26,9 \%$ dzieci miało wynik "nieprawidłowa” uwaga słuchowa. Po terapii Tomatisa $w$ grupie dzieci z zespołami zaburzeń genetycznych odnotowano aż 92,3\% wyników "poprawa” uwagi słuchowej wewnętrznej w odniesieniu do odsetka wyników testów uwagi słuchowej wewnętrznej wykonanych przed terapią. Najmniej wyników "poprawa” uwagi słuchowej wewnętrznej po terapii w uchu prawym odnotowano u dzieci z zaburzeniami zachowania (nieco ponad $50 \%$ wyników). Jednak nawet $\mathrm{w}$ tej grupie, pomimo uzyskania najniższego wyniku wśród wszystkich badanych grup, wystąpił znaczący wzrost odsetka wyniku „poprawa” uwagi słuchowej wewnętrznej w testach wykonanych po przeprowadzeniu terapii Tomatisa. 
Wyniki „nieprawidłowa” uwaga słuchowa wewnętrzna w badaniu przed terapią, w uchu lewym występowały u około połowy dzieci z poszczególnych grup badanych, przy czym najczęściej występowały one w grupie dzieci z zaburzeniami zachowania. Odsetek wyników „nieprawidłowa” uwaga słuchowa w grupie kontrolnej uzyskany podczas pierwszego badania był znacznie mniejszy niż w pozostałych grupach badanych i wynosił nieco ponad $17 \%$. Po terapii zaobserwowano znaczący wzrost odsetka wyników „poprawa” uwagi słuchowej wewnętrznej w uchu lewym w każdej z grup badanych. Największy wzrost odsetka wyników „poprawa” uwagi słuchowej w stosunku do wyników badania uzyskanych przed terapią Tomatisa zanotowano $\mathrm{w}$ grupie dzieci z zespołami zaburzeń genetycznych (u 90,5\%).

W tabeli 3. przedstawiono odsetek dzieci, u których w teście uwagi słuchowej - dyskryminacji wysokości dźwięku w uchu prawym oraz w uchu lewym przed terapią Tomatisa uzyskano wynik "nieprawidłowa” dyskryminacja wysokości dźwięku, oraz odsetek dzieci w poszczególnych grupach badanych, u których po terapii uzyskano wynik „poprawa” dyskryminacji wysokości dźwięku.

Tabela 3. Odsetek dzieci, u których w teście uwagi słuchowej uzyskano w uchu prawym i uchu lewym wynik „nieprawidłowa” dyskryminacja wysokości dźwięku, oraz odsetek dzieci, u których po terapii Tomatisa uzyskano wynik „poprawa”, z podziałem na poszczególne grupy badane i grupę kontrolną

\begin{tabular}{|c|c|c|c|c|c|c|}
\hline \multirow{3}{*}{ Grupa badana } & \multicolumn{4}{|c|}{ Ucho prawe } & \multirow{2}{*}{\multicolumn{2}{|c|}{$\begin{array}{c}\text { Ucho lewe } \\
\text { wyniki nieprawidłowe } \\
\text { przed terapią }\end{array}$}} \\
\hline & \multicolumn{2}{|c|}{$\begin{array}{c}\text { wyniki nieprawidłowe } \\
\text { przed terapią }\end{array}$} & \multicolumn{2}{|c|}{$\begin{array}{c}\text { efekt poprawy } \\
\text { po terapii }\end{array}$} & & \\
\hline & $\mathrm{N}$ & $\%$ & $\mathrm{~N}$ & $\%$ & $\mathrm{~N}$ & $\%$ \\
\hline $\begin{array}{l}\text { zaburzenia z zespołami } \\
\text { genetycznymi }\end{array}$ & 62 & 82,7 & 39 & 62,9 & 58 & 77,3 \\
\hline autyzm & 51 & 78,5 & 37 & 72,5 & 49 & 75,4 \\
\hline zaburzenia zachowania & 48 & 82,8 & 32 & 66,7 & 46 & 79,3 \\
\hline zaburzenia mowy & 57 & 78,1 & 39 & 68,4 & 53 & 72,6 \\
\hline $\begin{array}{l}\text { zaburzenia rozwoju } \\
\text { psychoruchowego }\end{array}$ & 60 & 83,3 & 30 & 50,0 & 56 & 77,8 \\
\hline $\begin{array}{l}\text { prawidłowy rozwój } \\
\text { psychofizyczny }\end{array}$ & 64 & 81,0 & 44 & 68,8 & 57 & 72,2 \\
\hline $\begin{array}{l}\text { grupa kontrolna } \\
\text { (bez terapii) }\end{array}$ & 0 & 0,0 & 0 & 0,0 & 5 & 9,6 \\
\hline
\end{tabular}

Źródło: Badania własne.

W poszczególnych grupach badanych w badaniu przeprowadzonym przed terapią uzyskano około $80 \%$ wyników „nieprawidłowa” dyskryminacja wysoko- 
ści dźwięku w uchu prawym. Najczęściej wyniki te występowały w grupie dzieci z zaburzeniami rozwoju psychoruchowego.

Po terapii wyniki „poprawa” w testach uwagi słuchowej-dyskryminacji wysokości dźwięku zaobserwowano u znacznej części dzieci z wynikami „nieprawidłowa" dyskryminacja wysokości dźwięku uzyskanymi przed terapią. W grupie dzieci z zaburzeniami rozwoju psychoruchowego u połowy (50\%) dzieci uzyskano po terapii wynik "poprawa” dyskryminacji wysokości dźwięku, ale największy wzrost odsetka wyników „poprawa” po terapii odnotowano u dzieci $\mathrm{z}$ autyzmem $(72,5 \%)$.

Podczas badania pierwszego przeprowadzonego w grupie kontrolnej blisko 10\% wyników dotyczących dyskryminacji wysokości dźwięków oceniono jako "nieprawidłowa” dyskryminacja wysokości dźwięków, natomiast podczas badania drugiego u wszystkich dzieci z wynikiem "nieprawidłowa” dyskryminacja wysokości dźwięków odnotowano wynik „poprawa” dyskryminacji wysokości dźwięków.

W poszczególnych grupach badanych wynik "poprawa” dyskryminacji wysokości dźwięków po przeprowadzeniu terapii Tomatisa wahał się od 48,3\% u dzieci z zespołami zaburzeń genetycznych do $78,3 \%$ w grupie dzieci z zaburzeniami zachowania.

W każdej z grup po terapii Tomatisa zaobserwowano znaczący wzrost wyników „poprawa” dyskryminacji wysokości dźwięków w testach uwagi słuchowej, zarówno w uchu prawym, jak i lewym.

W tabeli 4 przedstawiono liczbę oraz odsetek wyników „zaburzona” lokalizacja dźwięku w uchu prawym, uzyskanych w testach uwagi słuchowej przeprowadzonych przed terapią Tomatisa w poszczególnych grupach badanych oraz liczbę i odsetek wyników „poprawa” lokalizacji dźwięku w testach wykonanych po terapii, jak również wyniki w grupie kontrolnej w badaniu 1 i 2 .

Wyniki „zaburzona" lokalizacja dźwięku uzyskane w teście uwagi słuchowej $\mathrm{w}$ przynajmniej jednym $\mathrm{z}$ analizowanych pasm częstotliwości występowały u około 1/3 dzieci w poszczególnych grupach badanych. Najczęściej wynik „zaburzona" lokalizacja dźwięku występował w grupie dzieci z zaburzeniami mowy $(35,6 \%)$. W grupie kontrolnej wynik „zaburzona” lokalizacja dźwięku uzyskano podczas badania pierwszego u 4 dzieci $(7,7 \%)$.

Po terapii metodą Tomatisa u prawie wszystkich dzieci odnotowano wynik „poprawa” lokalizacji dźwięku widoczny w testach uwagi słuchowej. U wszystkich dzieci z zaburzeniami zachowania i u dzieci z zespołami zaburzeń genetycznych wynik, u których stwierdzono „zaburzoną” lokalizację dźwięku w badaniu wykonanym przed terapią, po terapii uzyskano wynik "poprawa” lokalizacji dźwięku. 
Tabela 4. Liczba i odsetek dzieci z poszczególnych grup badanych, u których w testach uwagi słuchowej uzyskano w uchu prawym wynik „zaburzona” lokalizacja dźwięku oraz liczba i odsetek dzieci, u których po terapii Tomatisa uzyskano wynik „poprawa”, oraz wyniki w grupie kontrolnej uzyskane w badaniu 1 i 2

\begin{tabular}{|c|c|c|c|c|c|c|}
\hline \multirow{3}{*}{ Grupa badana } & \multicolumn{4}{|c|}{ Ucho prawe } & \multirow{2}{*}{\multicolumn{2}{|c|}{$\begin{array}{c}\text { Ucho lewe } \\
\begin{array}{c}\text { wyniki nieprawidłowe } \\
\text { przed terapią }\end{array}\end{array}$}} \\
\hline & \multicolumn{2}{|c|}{$\begin{array}{l}\text { wyniki nieprawidłowe } \\
\text { przed terapią }\end{array}$} & \multicolumn{2}{|c|}{$\begin{array}{l}\text { efekt poprawy } \\
\text { po terapii }\end{array}$} & & \\
\hline & $\mathrm{N}$ & $\%$ & $\mathrm{~N}$ & $\%$ & $\mathrm{~N}$ & $\%$ \\
\hline $\begin{array}{l}\text { zaburzenia z zespołami } \\
\text { genetycznymi }\end{array}$ & 22 & 29,3 & 22 & 100,0 & 17 & 22,7 \\
\hline autyzm & 21 & 32,3 & 20 & 95,2 & 20 & 30,8 \\
\hline zaburzenia zachowania & 12 & 20,7 & 12 & 100,0 & 18 & 31,0 \\
\hline zaburzenia mowy & 26 & 35,6 & 25 & 96,2 & 25 & 34,2 \\
\hline $\begin{array}{l}\text { zaburzenia rozwoju } \\
\text { psychoruchowego }\end{array}$ & 23 & 31,9 & 21 & 91,3 & 24 & 33,3 \\
\hline $\begin{array}{l}\text { prawidłowy rozwój } \\
\text { psychofizyczny }\end{array}$ & 26 & 32,9 & 24 & 92,3 & 19 & 24,1 \\
\hline $\begin{array}{l}\text { grupa kontrolna } \\
\text { (bez terapii) }\end{array}$ & 4 & 7,7 & 4 & 100,0 & 4 & 7,7 \\
\hline
\end{tabular}

Źródło: Badania własne.

Podobnie jak w teście uwagi słuchowej dotyczącym lokalizacji wykonywanym dla ucha prawego, również w teście uwagi słuchowej - lokalizacji wykonanym przed terapią dla ucha lewego stwierdzono w poszczególnych grupach badanych zbliżony odsetek wyników „zaburzona” lokalizacja dźwięku. Najrzadziej wynik „zaburzona" lokalizacja dźwięku występował w grupie dzieci z zespołami zaburzeń genetycznych (22,7\%), natomiast najczęściej wynik „zaburzona” lokalizacja dźwięku występował w grupie dzieci z zaburzeniami mowy $(34,2 \%)$.

Poprawę wyników w testach uwagi słuchowej dotyczących lokalizacji dźwię$\mathrm{ku}$ przeprowadzonych po terapii Tomatisa zaobserwowano u znacznej części dzieci. Największy odsetek wyników "poprawa” lokalizacji dźwięku odnotowano u dzieci z zespołami zaburzeń genetycznych $(100 \%)$ oraz u dzieci z zaburzeniami rozwoju psychoruchowego (100\%). Najniższy odsetek wyników "poprawa” lokalizacji dźwięku po terapii występował w grupie dzieci z autyzmem (75\%).

Uzyskane wyniki analiz parametrów testu uwagi słuchowej zewnętrznej i wewnętrznej pokazują obraz dynamicznej zmiany tych parametrów, jaka zaszła po zastosowaniu terapii Tomatisa. Po analizie statystycznej wyników testów uwagi słuchowej wykonanych przed terapią Tomatisa i po jej przeprowadzeniu możemy stwierdzić, że po terapii Tomatisa uzyskano wyniki "poprawa” uwagi słuchowej, różne dla poszczególnych grup badanych. Możemy zatem przyjąć, że 
terapia słuchowa metodą Tomatisa wpływa na zmianę parametrów testów uwagi słuchowej.

\section{Dyskusja}

Z obserwacji prowadzonych w Klinice Audiologii i Foniatrii Instytutu Fizjologii i Patologii Słuchu wynika, że istotne problemy diagnostyczne i terapeutyczne w przypadku dzieci z zaburzeniami uwagi słuchowej spowodowane są faktem, że przeprowadzane $u$ nich standardowe badania audiologiczne, oceniające przede wszystkim funkcjonowanie ucha zewnętrznego, środkowego i wewnętrznego, na ogół nie wykrywają tej patologii. U dzieci z zaburzeniami uwagi słuchowej często mamy do czynienia z prawidłowym audiogramem, bez żadnych odchyleń od normy [Rogalsky, Rong i in. 2011]. Natomiast analiza parametrów związanych $\mathrm{z}$ aktywnym procesem poznawczym, jakim jest uwaga słuchowa, nie jest rutynowo stosowana w diagnostyce. Biorąc zatem pod uwagę skalę problemu, negatywny wpływ zaburzeń uwagi słuchowej na szeroko rozumiany rozwój dziecka, jak i opisane trudności diagnostyczne i terapeutyczne, wydaje się, że wdrożenie testu uwagi słuchowej do diagnostyki zaburzeń percepcji słuchowej u dzieci z trudnościami szkolnymi i z prawidłowym progiem słyszenia może stać się ważnym elementem programowania efektywnych działań terapeutycznych. Wśród działań tych metodą o udowodnionej skuteczności jest trening słuchowy przeprowadzany za pomocą specjalnego urządzenia zwanego „elektronicznym uchem", znany jako metoda Tomatisa. Metoda ta po raz pierwszy została wprowadzona w naszym kraju w 1999 roku przez Instytut Fizjologii i Patologii Słuchu. Ten nieinwazyjny program stymulacji dźwiękowej był wykorzystywany w terapii dzieci i dorosłych z zaburzeniami głosu, mowy oraz stosowany wspomagająco u uczniów mających trudności szkolne.

Zagadnienie diagnozy uwagi słuchowej i jej zmian pod wpływem stymulacji słuchowej, mierzonych testem uwagi słuchowej, jest opisane w stosunkowo małej liczbie prac literaturowych. Uwaga słuchowa, jako proces aktywny, zmieniający się wraz z wiekiem dziecka, przechodzi stopniowy rozwój od strategii mimowolnej do świadomej selekcji percepcyjnej. Dzieje się to dzięki dojrzewaniu centralnego układu nerwowego oraz procesowi uczenia się, dzięki czemu następuje wzrost poziomu dojrzałości uwagi słuchowej [Vasta i in. 2004]. Ocena taka wydaje się być to zbieżna z wynikami otrzymanymi przy analizach testów uwagi słuchowej dokonanych przez autorów niniejszej pracy. W grupie kontrolnej, w której nie zastosowano żadnej stymulacji dźwiękowej, także nastąpiła poprawa w zakresie zarówno parametru testu uwagi słuchowej zewnętrznej, jak i wewnętrznej 
dla percepcji prawousznej i lewousznej. Pomimo iż wynik testu uwagi słuchowej uzyskany $\mathrm{w}$ grupie kontrolnej $\mathrm{w}$ badaniu pierwszym był lepszy niż u dzieci z grup badanych, to w badaniu drugim dynamika zmiany była zdecydowanie niższa niż u dzieci z innych grup badanych poddanych stymulacji dźwiękowej. Uzyskane w większości przypadków wyniki poprawy w teście uwagi słuchowej, zarówno zewnętrznej jak i wewnętrznej, dla percepcji prawousznej i lewousznej, po zastosowaniu stymulacji słuchowej metodą Tomatisa różnią się w poszczególnych grupach, co może wynikać m.in. z istnienia u tych dzieci dodatkowych deficytów. Na szczególną uwagę zasługuje analiza progów słuchania u dzieci z nadpobudliwością psychoruchową, gdzie efekt poprawy wyników w zakresie badanych parametrów testu uwagi słuchowej dla ucha prawego był zdecydowanie słabszy niż u dzieci z innych grup badanych. Być może nadmierna aktywność psychoruchowa przeszkadza dzieciom z zespołami zaburzeń zachowania w prawidłowej prawousznej percepcji dźwięków, w tym również dźwięków mowy. Doświadczenia własne jak również badania przeprowadzone przez Kurkowskiego zdają się potwierdzać, że nadmierna aktywność motoryczna przeszkadza dziecku w mówieniu i słuchaniu [Kurkowski 2013]. Vasta podkreśla w swojej pracy, że zmienna jakość uwagi słuchowej może wpływać na obniżenie potencjału w zakresie uczenia się, szczególnie w przypadku dzieci [Vasta i in. 2004]].

Podsumowując wyniki badań nad uwagą słuchową zewnętrzną i wewnętrzną dla percepcji prawousznej i lewousznej, możemy stwierdzić zmienną specyfikę percepcji słuchowej $\mathrm{w}$ omawianych grupach badawczych, przejawiającą się różnym poziomem tej uwagi i tym samym różną wrażliwością na dźwięki odbierane drogą powietrzną i kostną.

Autorzy badań nad testem uwagi słuchowej zwracają uwagę na szczególnie ważną rolę dyskryminacji wysokości dźwięku w kontekście percepcji mowy [Kurkowski 2013]. Można zauważyć zbieżność otrzymanych przez autorów wyników testu uwagi słuchowej - dyskryminacji z wynikami innych badaczy. Podkreślają oni, że zaburzenia słuchania, a w szczególności problemy z różnicowaniem wysokości dźwięków, utrzymujące się do wieku szkolnego mogą powodować u dzieci trudności w zakresie nabywania kompetencji szkolnych oraz współistnieją z zaburzeniami koncentracji, trudnościami w nauce czytania i pisania, zaburzeniami głosu, mowy oraz zaburzeniami zachowania [Kurkowski 2013, Szkiełkowska 2012]. A zatem wykazany w niniejszej pracy efekt poprawy wyników w teście uwagi słuchowej - dyskryminacji w grupie dzieci z zaburzeniami zachowania może wskazywać, że terapia słuchowa może być skuteczną metodą poprawiającą u dzieci również umiejętność kontroli swojego zachowania. Występujące w grupie dzieci z zaburzeniami mowy trudności w zakresie różnicowania wysokości dźwięków mogą wskazywać, że problemy w opanowaniu prawidłowej mowy oraz w nauce czytania i pisania mogą mieć źródło w niewykształconej umiejętno- 
ści odbioru dostarczanego sygnału akustycznego, w tym również mowy. Wydaje się zatem słuszne, że przy programowaniu działań terapeutycznych mających na celu poprawę poziomu uwagi słuchowej należy brać pod uwagę działania zmierzające do podniesienia sprawności w zakresie umiejętności dyskryminacji wysokości dźwięku. Z danych literaturowych wynika, że istnieje korelacja pomiędzy występowaniem zaburzeń dyskryminacji wysokości dźwięku a zaburzeniami koncentracji [Summers 2003]. Autorzy licznych prac dotyczących zaburzeń funkcji percepcyjnych wskazują na istnienie związku pomiędzy wyższymi procesami słuchowymi a rozwojem funkcji poznawczych dziecka, które z kolei determinują umiejętności szkolne [Bishop 1992; Conti-Ramsden, Bolting 1999; Leonard 1991; Rapin 1996; Szkiełkowska, Senderski i in. 2006; Szkiełkowska, Włodarczyk i in. 2009]. Można zatem zaproponować, aby test uwagi słuchowej przeprowadzany był $\mathrm{u}$ dzieci rozpoczynających naukę w klasie pierwsze. Umiejętność lokalizacji dźwięku to kolejny parametr badany w teście uwagi słuchowej. Lokalizacja dźwięku wpływa na proces edukacji szkolnej, ponieważ kształtuje umiejętności koordynacji słuchowo-wzrokowo-ruchowej, a wszelkie zaburzenia w tych obszarach mogą rzutować na rozwój mowy, a później na umiejętność czytania i pisania [Cieszyńska 2011].

Przeprowadzone analizy statystyczne poziomów uwagi słuchowej wskazują, że istnieje zależność pomiędzy dynamiką przebiegu parametrów testu uwagi słuchowej a treningiem słuchowym metodą Tomatisa. Wykazano istotne statystycznie zmiany parametrów testów uwagi słuchowej analizowanych w poszczególnych grupach badawczych po zastosowaniu treningu słuchowego metodą Tomatisa. Analiza różnic w poziomach uwagi słuchowej u badanych dzieci po terapii metodą Tomatisa wskazuje na wyraźnie lepsze wyniki w zakresie uwagi słuchowej niż u dzieci z grupy kontrolnej niepoddanych treningowi. Zjawisko to opisała również w swojej pracy Szkiełkowska, wskazując na występowanie zależności pomiędzy procesami stymulacji dźwiękowej a dynamiką przebiegu parametrów testów uwagi słuchowej u pacjentów z guzkami głosowymi poddanych terapii metodą Tomatisa [Szkiełkowska 2012]. Autorka wykazała korzystny wpływ tej terapii na regulację procesów percepcyjnych w zakresie uwagi słuchowej u dzieci z zaburzeniami głosu.

Trening muzyczny, zdaniem niektórych badaczy, kształtuje funkcję słuchową poprzez wpływ na mózg, rozwijając w większym stopniu zmysłowe mechanizmy powiązane z kontrolą funkcji poznawczych, takich jak pamięć operacyjna i uwaga słuchowa, oraz wpływa na realizację innych zadań słuchowych [Baumann, Meyer i in. 2008; Bohme 2003; Gaab, Schlaug 2003; Stewart, Henson i in. 2003]. $W$ Polsce i na świecie prowadzone są różnorodne formy oddziaływania terapeutycznego z wykorzystaniem muzyki. W większości bazują one jednak na obserwacjach i doświadczeniach A. Tomatisa. Tomatis, dzięki opracowanej przez siebie 
innowacyjnej technice stymulacji połączeń między uchem i układem nerwowym przez specjalnie skonstruowane urządzenie "ucho elektroniczne", oddziaływał na zintegrowanie aspektów słuchania, mowy i zachowania człowieka wskutek usprawniania procesów percepcji dźwięku.

Prawie 50 lat doświadczeń klinicznych zebranych i opisanych w wielu publikacjach przez samego Tomatisa oraz badania prowadzone przez naukowców i terapeutów na całym świecie wskazują, że stymulacja dźwiękiem z wykorzystaniem metody Tomatisa może stanowić cenne narzędzie rozwoju możliwości audio-psycho-lingwistycznych zarówno dla dzieci, jak i dla dorosłych [www.tomatisassociation.org].

Badania przeprowadzone przez Young Digital Planet $\mathrm{w}$ Polsce $\mathrm{w}$ latach 2010-2013 wykazały różnice w przyroście kompetencji szkolnych między dziećmi poddanymi terapii Tomatisa i dziećmi, które nie były poddane tej terapii. Korzystne różnice stwierdzone u dzieci, które przeszły terapię, dotyczyły: umiejętności uczenia się (pamięć, uwaga, wykorzystanie wiedzy w praktyce, motywacja i wiara we własne możliwości), kompetencji społecznych (umiejętność pracy w grupie, rozumienie i respektowanie reguł i zasad, wyrażanie i rozumienie różnych punktów widzenia), kompetencji językowych (percepcja mowy, ekspresja mowy i wrażliwość na język mówiony) oraz kompetencji muzycznych (percepcja muzyki) [www.tomatisassociation.org]. Stutt stwierdził, że program słuchania terapeutycznego z wykorzystaniem metody Tomatisa przynosi korzyści niezależnie od przebiegu procesów dojrzewania dziecka lub edukacji, w postaci: znaczącego wzrostu ilorazu inteligencji, lepszych umiejętności czytania, lepszego przetwarzania percepcyjnego, zwiększenia umiejętności uczenia się, lepiej rozwiniętych umiejętności komunikacyjnych oraz większej zdolności do werbalnego wyrażania myśli i odczuć [sites.google.com/site/thesoundgate/research]. Zaburzenia słuchania mogą wywoływać u dzieci w wieku szkolnym zniekształcony odbiór dźwięków świata zewnętrznego. Charakteryzuje je brak koncentracji, nadwrażliwość na niektóre dźwięki, niepokój nerwowy, zaburzenia głosu, wymowy, nieczytelne pismo, problemy z czytaniem i tym samym trudności szkolne.

\section{Podsumowanie}

Biorąc pod uwagę częstość występowania zaburzeń uwagi słuchowej u dzieci rozpoczynających naukę $\mathrm{w}$ szkole, można rozważać zaburzenia te jako jedną z przyczyn uzyskiwania przez te dzieci gorszych wyników w nauce. Analiza testów uwagi słuchowej przed i po terapii zdaje się potwierdzać zasadność stosowania stymulacji słuchowej z wykorzystaniem metody Tomatisa jako formy oddziaływania terapeutycznego u dzieci mających nieprawidłowe wyniki w testach 
uwagi słuchowej. Zastosowanie interwencji w postaci treningu słuchowego metodą Tomatisa wpływa na poprawę procesów uwagi słuchowej. Trening słuchowy metodą Tomatisa może być wykorzystany jako strategia terapeutyczna $\mathrm{w}$ rehabilitacji, dla dzieci mających trudności w obszarze słuchowo-emocjonalno-językowym umożliwiająca skuteczną pomoc przy zaburzeniach procesów przetwarzania słuchowego. Otrzymane wyniki analizy poziomów uwagi słuchowej wydają się być interesujące i można je uznać za wskaźnik do oceny procesów uwagi słuchowej przed zastosowaniem i po zastosowaniu treningu słuchowego w różnych grupach wiekowych. Przeprowadzone analizy mogą wskazywać również, iż test przeznaczony do oceny uwagi słuchowej jest przydatnym narzędziem umożliwiającym diagnozę uwagi słuchowej u dzieci.

Rekomendacją dla zastosowania testu uwagi słuchowej w diagnostyce zaburzeń percepcji słuchowej jest możliwość wykorzystania go w codziennej, interdyscyplinarnej praktyce wykraczającej poza obszar medycyny. Może on być przydatny dla pedagogów, psychologów, logopedów chcących poszerzyć ocenę funkcji słuchowych u dziecka. Biorąc pod uwagę fakt, że test uwagi słuchowej jest stosunkowo nową metodą diagnostyczną, jego wiarygodność może budzić wątpliwości. Dlatego w celu potwierdzania jego skuteczności klinicznej istnieje potrzeba kontynuowania wielośrodkowych prac badawczych, z udziałem zróżnicowanych grup pacjentów.

\section{Bibliografia}

Baumann S., Meyer M., Jäncke L. (2008), Enhancement of auditory-evoked potentials in musicians reflects an influence of expertise but not selective attention, "J Cogn Neurosci", 20(12), s. $2238-2249$.

Bishop D.V.M. (1992), The underlying nature of specific language impairment, "Journal of Child Psychology and Psychiatry", 33(1), s. 3-66.

Bohme G.(2003), Sprach-Sprech, Stimm - und Schluckstörungen, Urban Fischer, Munchen, Jena.

Cieszyńska J.(2011), Wczesna diagnoza i terapia zaburzeń autystycznych, Wydawnictwo Omega Stage Systems - Jędrzej Cieszyński, Kraków.

Conti-Ramsden G., Bolting N. (1999), Classification of children with specific language impairment: Longitudinal consideration, "Journal of Speech, Language and Hearing Research", 42, s. 1194-1204.

Gaab N., Schlaug G. (2003), The effect of musicianship on pitch memory in performance matched groups, „Neuroreport”, 14(18), s. 2291-2295.

Gopnik M., Cargo M. (1991), Familial aggregation of developmental language disorder, „Cognition:, 39, s. 1-50.

Kurkowski Z.M. (2013), Audiogenne uwarunkowania zaburzeń komunikacji językowej, Wydawnictwo Uniwersytetu Marii Curie-Skłodowskiej, Lublin. 
Kurkowski Z.M., Szkiełkowska A., Ratyńska J., Markowska R., Mularzuk M. (2002), Zastosowanie Metody Tomatisa w terapii osób z zaburzeniami komunikacji językowej. Doniesienia wstępne, "Audiofonologia", XXII, s. 203-210.

Leonard L.(1991), Specific language impairment as clinical category, "Language, Speech and Hearing Services in School", 22, s. 66-68.

Rapin I.(1996), Practicioner review: Developmental language disorder: clinical update, "Journal od Child Psychology and Psychiatry",6, s. 643-655.

Pruszewicz A. (red.) ( 2003), Zarys audiologii klinicznej, WAM, Poznań.

Rogalsky C., Rong F., Saberi K., Hickok G. ( 2011), Functional anatomy of language and music perception: temporal and structural factors investigated using functional magnetic resonance imaging, "J. Neurosci", 31, s. 3843-3852.

Skarżyński H., Czyżewski A., Senderski A., Bruski Ł., Skarżyński P.H.(2007), Multi-year experience in application of multimedia hearing screening programs "I can hear" and "I can speak.", EUFOS, Vienna.

Stewart L., Henson R., Kampe K., Walsh V., Turner R., Frith U. (2003), Brain changes after learning to read and play music, "Neuroimage”, 20(1), s. 71-83.

Summers S.A. (2003), Factor structure, correlations and mean data on form a of the Beta III version of Multiple Auditory Processing Assesment (MAPA), Masters Thesis, Idaho State University, Pocatello, ID.

Szkiełkowska A., Senderski A., Ratyńska J., Markowska R., Kurkowski M., Mularzuk M. (2006), Zaburzenia procesów przetwarzania stuchowego u dzieci z dysleksją rozwojowa, „Biuletyn Informacyjny Oddziału Warszawskiego Polskiego Towarzystwa Dysleksji", 32, s. 194-198.

Szkiełkowska A., Włodarczyk E., Senderski A., Ganc M., Skarżyński H.(2009), Ocena procesów przetwarzania stuchowego u dzieci z dyslalia, "Otolaryngologia Polska”, LXIII/I, s. 54-57.

Szkiełkowska A. (2012), Ocena wyższych procesów stuchowych, Instytut Fizjologii i Patologii Słuchu, Warszawa.

Szuman S. (1963), O dojrzałości szkolnej dzieci siedmioletnich, Nowa Szkoła; 7: 302-303.

Ullman M., Gopnik M. (1994), Past tense production: Regular, irregular and nonsense verbs, „McGill Working Pepers in Linguistics”, 10, s. 81-118.

Vasta R., Haith M., Miller S.A. (2004), Psychologia dziecka, Wydawnictwo WSiP, Warszawa. Weiner P. (1974), A language-delayed child at adolescence, "Journal of Speech and Hearing Disorders", 39, s. 202-212.

www.tomatisassociation.org/

sites.google.com/site/thesoundgate/research/ 